\title{
POLYPHENOLIC PROFILE AND ANTIMICROBIAL POTENTIAL OF PEEL EXTRACTS OBTAINED FROM ORGANIC POMEGRANATE (PUNICA GRANATUM L.) VARIETY "MOLLAR DE ELCHE"
}

\author{
Marina CANO-LAMADRID*, Manuel VIUDA-MARTOS, José Miguel GARCÍA-GARVÍ, Jesús CLEMENTE- \\ VILLALBA, Ángel A. CARBONELL-BARRACHINA, Esther SENDRA \\ Universidad Miguel Hernández, Orihuela, Spain
}

\begin{abstract}
The aim of this work was to determine the polyphenolic profile and the antibacterial properties of extracts from organic pomegranate peel, to evaluate if it could be used as a potential antimicrobial ingredient to elaborated organic food. The antibacterial properties of different organic pomegranate peel extracts (ethyl acetate, acetone and methanol, with an increasing polarity) were tested against: Listeria innocua, Achromobacter denitrificans and Algaligenes faecalis. All extracts showed antimicrobial activity against all bacteria tested except ethyl acetate extract against $A$. denitrificans. The polyphenolic profile was determined by High Performance Liquid Chromatography (HPLC). Five compounds were identified. Punicagalin was the main component found in acetone and methanol extracts $\left(7,939 \mu \mathrm{g} \cdot \mathrm{g}^{-1}\right.$ and $5,178 \mu \mathrm{g} \cdot \mathrm{g}^{-1}$ of lyophilized sample, respectively). Ellagic acid was the main component found in ethyl acetate extract (171 $\mu \mathrm{g} \cdot \mathrm{g}^{-1}$ of lyophilized sample).
\end{abstract}

Keywords: antibacterial activity, ellagic acid, punicalagin, polyphenolic compounds

Consumers have been questioning the safety of synthetic preservatives of food (Al-Zoreky, 2009). As a result, there is an increasing demand for natural products which could serve as alternative food preservatives (Tajkarimi, Ibrahim, and Cliver, 2010; Tehranifar et al., 2011). One of them could be the co-products generated in the industrial transformation of vegetables and fruits, insomuch as these are potentially good sources of bioactive compounds (Ayala-Zavala et al., 2011). In this way, during the industrial processing of pomegranate juice, the wastes (mainly peel and internal membranes) on average account for $50 \%$ of the fresh weight. In the last recent years, little attention has been paid to pomegranate non-edible parts (Hasnaoui, Wathelet, and Jiménez-Araujo, 2014). Pomegranate peel is a rich source of polyphenolic compounds, which possess antibacterial properties (Al-Zoreky, 2009; Agourram et al., 2013). A linear relationship between total phenolic content and antibacterial activity against several microorganisms has been previously reported (Shan et al., 2007).

In our knowledge, this is the first study where the polyphenolic profile of organic certified pomegranate peel extracts and their antimicrobial properties are evaluated against listeria and other bacteria from refrigerated foods. Thus, the aim of this work was to determine the polyphenolic profile and the antibacterial properties of different organic pomegranate peel extracts (acetone, methanol and ethyl acetate based extracts), to know if they could be used as potential antimicrobial ingredients to be included in organic foods.

\section{Material and method}

\section{Plant material}

Ripe pomegranate fruits, variety "Mollar de Elche", were obtained from an organic field certified by CAERM (Council Agriculture the Ecological Region of Murcia) in Alquerias (Murcia). Pomegranate peel (PoP) was obtained following the procedure described by Gullón et al. (2016). After that, the sample was lyophilized and stored under vacuum until analyzed.

\section{Determination of polyphenolic compounds}

\section{Extraction of polyphenolic compounds}

The method run was described by Gullón et al. (2016). The solvents used were: ethyl acetate (ea), $70 \%$ acetone in water (ac) and $80 \%$ methanol in water $(\mathrm{m})$ with an increasing polarity. Three replicates were performed for each extraction in order to calculate extraction yield, which was calculated after removing the extraction solvents. Extracts were named: PoP methanol (PoPm), PoP acetone (PoPac) and PoP ethyl acetate (PoPea).

\section{HPLC analysis}

The determination of the phenolic compounds using High Performance Liquid Chromatography (HPLC) was performed on a Hewlett-Packard HPLC series 1,200 instrument (Woldbronn, Germany) equipped with UV-Vis Diode Array

Contact address: Marina Cano-Lamadrid, Research Personel, Universidad Miguel Hernández de Elche, Departamento Tecnología Agroalimentaria, Grupo Calidad y Seguridad Alimentaria, Carretera de Beniel, km 3.2, Orihuela 03312, Spain, rer 966749735, e-mail: marina.cano.umh@gmail.com 
Detector following Gullón et al. (2016). The compounds were quantified through calibration curves of standard compounds as mean of three replicates.

\section{Antimicrobial activity}

\section{Microorganisms and growth conditions}

Each pomegranate peel extract (PoPx) were was individually tested against bacterial strains which are common spoilage agents or indicators of the presence of pathogenic bacteria in refrigerated foods: Listeria innocua CECT 910, Achromobacter denitrificans CECT 449 and Alcaligenes faecalis CECT 145. These species were supplied by the Spanish Type Culture Collection of the University of Valencia (CECT).

\section{Minimum inhibitory concentration (MIC)}

The antimicrobial activity against bacteria species was determined based on a method proposed by Abate, Mshana, and Miorner, (1998), with some modifications. Bacteria were cultured in Mueller Hinton $(\mathrm{MH})$ broth for $24 \mathrm{~h}$ at $37^{\circ} \mathrm{C}$ (L. innocua, A. denitrificans and A. faecalis) and diluted in sterile $\mathrm{MH}$ broth to a final level of $10^{6}$ colony forming units (CFU) $\mathrm{mL}^{-1}$. Dried organic PoPx obtained with ethyl acetate, acetone $70 \%$ and methanol $80 \%$ were suspended to concentration ranges from 50 to $100 \mathrm{mg} \cdot \mathrm{mL}^{-1}$ in $\mathrm{MH}$ and sterilized by filtration though a $0.22 \mu \mathrm{m}$ nylon filter. The 96-well microplates (Iwaki, Japan) were prepared by dispensing the extracts (the concentration of the extracts on the media tested on the microplates ranged from 20 microliters $/ \mathrm{mL}$ to 0.009 microliters. $\mathrm{mL}^{-1}$ ), fresh media and $20 \mu \mathrm{L}$ of microbial suspension (containing about $10^{6} \mathrm{CFU} \cdot \mathrm{mL}^{-1}$ ) to a total volume of $300 \mu \mathrm{L}$. Contents of each well were mixed on a plate shaker at $150 \mathrm{rpm}$ for $2 \mathrm{~min}$ prior to incubation for $24 \mathrm{~h}$ at $37^{\circ} \mathrm{C}$. After incubation, $25 \mu \mathrm{L}$ of 3-(4.5-dimethylthiazol-2-yl)-2.5-diphenyl tetrazolium bromide (MTT) (Sigma Life Science), dissolved in dimethyl sulfoxide (DMSO) was added to each of the wells and incubated for $1 \mathrm{~h}$ in order to allow the viable microorganisms to metabolize the yellow MTT dye into formazan (purple crystals). The MIC was the concentration of the first well that did not undergo colour change (from yellow to purple). Results were confirmed by plating $10 \mathrm{~mL}$ samples from clear wells onto $\mathrm{MH}$ agar medium. The procedure was repeated three times for each microorganism.

\section{Well diffusion method}

The antibacterial action of the PoPx $\left(100 \mathrm{mg} \cdot \mathrm{mL}^{-1}\right)$ was tested on bacteria described using the well diffusion method (Smith-Palmer, Stewart, and Fyfe, 1998). Wells were aseptically made in the agar at the center of the plate, in order to add $100 \mu \mathrm{L}$ of the extract. The inhibition zones around the wells were measured using a transparent millimeter ruler. Two zones were identified as bactericidal and bacteriostatic (Smith-Palmer, Stewart, and Fyfe, 1998). For each extract and microorganism tested, three replicates were made.

\section{Statistical assay}

Results are provided as the mean \pm standard error. First, data was subjected to one-way (factor = extract) analysis of variance (ANOVA) and later, data was also subjected to the Tukey's multiple-range test to compare the means. Differences were considered statistically significant at $p<0.05$. All statistical analyses were performed using StatGraphics Plus 5.0 software (Manugistics, Inc., Rockville, MD).

\section{Results and discussion}

\section{Polyphenolic profile}

The extraction yield of the extracts was in a decreasing order: Acetone > Methanol > Ethyl acetate $(86.5,67.5$ and 3.8\%, respectively). The effect of the solvent used for extraction showed significant differences $(p<0.05)$ on the extraction yield. In most of published researches on phenolic extraction (Al-Zoreky, 2009; Akhtara et al., 2015; Nuncio-Jáuregui et al., 2015), the solvent used was methanol or methanol-water given their high extraction yield, however, in this work the most effective solvent was acetone-water, although methanol extraction yield was also high. Table 1 shows the HPLC profile of the three PoPx. A total of five phenolic compounds were identified as punicalagins $(P C)$, ellagic acid (EA) and ellagic acid derivatives $\left(\mathrm{EAd}_{1}, \mathrm{EAd}_{2}\right.$ and $\left.E \mathrm{Ed}_{3}\right)$ in all extracts except $E \mathrm{Ad}_{1}$ which was not detected in PoPea. In this work, PC is the sum of both isomers ( $\alpha$-punicalagin and $\beta$-punicalagin) as usually reported by other authors (Calín-Sánchez et al., 2013; Nuncio-Jáuregui et al., 2015).

Table $1 \quad$ Polyphenolic profile of organic pomegranate peel extracts (PoPx)

\begin{tabular}{|c|c|c|c|}
\hline \multirow[t]{2}{*}{ Compound } & \multicolumn{3}{|c|}{ Lyophilized Organic PoPx $\left(\mu \mathbf{g} \cdot \mathbf{g}^{-1}\right)$} \\
\hline & PoPm & PoPac & PoPea \\
\hline Punicalagin & $5,177 \pm 249^{b *}$ & $7,939 \pm 103^{a}$ & $14 \pm 5^{c}$ \\
\hline Ellagic acid & $603 \pm 12^{b}$ & $1,026 \pm 17^{\mathrm{a}}$ & $171 \pm 3^{c}$ \\
\hline Ellagic acid derivate 1 & $823 \pm 80^{b}$ & $1,026 \pm 12^{\mathrm{a}}$ & $\mathrm{nd}^{* *}$ \\
\hline Ellagic acid derivate 2 & $293 \pm 8^{b}$ & $494 \pm 4^{\mathrm{a}}$ & $20 \pm 2^{c} 9$ \\
\hline Ellagic acid derivate 3 & $283 \pm 10^{b}$ & $528 \pm 6^{\mathrm{a}}$ & $22 \pm 8^{c}$ \\
\hline
\end{tabular}

PoPm - 80\% methanol extract; PoPac - 70\% acetone extract; PoPea - ethyl acetate extract; ${ }^{*}$ - values followed by different letter within the same line were statistically different according to the Tukey's multiple range test, $(p<0.05)$; nd $d^{* *}$ - below LOQ [limit of quantification determined as three times the standard deviation of the blanks, limit of detection (LOD), multiplied by the proper dilution factor] 
Table 2

Minimum inhibitory concentration (MIC) of organic pomegranate peel extracts (PoPx) against $L$. innocua, $A$. faecalis and $A$. denitrificans

\begin{tabular}{|c|c|c|c|}
\hline \multirow[t]{2}{*}{ Microorganism } & \multicolumn{3}{|c|}{ MIC (mg.mL $\left.{ }^{-1}\right)$} \\
\hline & PoPm & PoPac & PoPea \\
\hline Listeria innocua CECT 910 & $50^{*}$ & 50 & 50 \\
\hline Alcaligenes faecalis CECT 145 & $70^{b}$ & $70^{b}$ & $100^{\mathrm{a}}$ \\
\hline Achromobacter denitrificans CECT 449 & $100^{\mathrm{a}}$ & $80^{b}$ & $N A^{* *}$ \\
\hline
\end{tabular}

PoPm - 80\% methanol extract; PoPac - 70\% acetone extract; PoPea - ethyl acetate extract; * - values followed by different letter within the same line were statistically different according to the Tukey's multiple range test $(p<0.05)$; NA** not active

Table 3 Antibacterial effects of PoPx $\left(100 \mathrm{mg}^{-1} \mathrm{~mL}^{-1}\right)$ on each bacteria studied, applying the diffusion method

\begin{tabular}{|l||c|c|c|}
\hline \multicolumn{1}{|l||}{ Microorganism } & \multicolumn{2}{c|}{ Diameter of inhibition zone (mm) * } \\
\cline { 2 - 4 } & PoPm & PoPac & PoPea \\
\hline \hline \multirow{2}{*}{ Listeria innocua CECT 910 } & $2.4 \pm 0.2$ & $1.9 \pm 0.3$ & $1.4 \pm 0.1(0.9 \pm 0.1)$ \\
\hline Alcaligenes faecalis CECT 145 & $(1.2 \pm 0.1)$ & $\mathrm{nd} \pm 0.1)$ & $\mathrm{nd}$ \\
\hline Achromobacter denitrificans CECT 449 & $\mathrm{nd} * *$ & $\mathrm{nd}$ \\
\hline
\end{tabular}

* - the values shown are the mean averages for three replications; ${ }^{* *}$ - no inhibition detected; Values within brackets indicate bactericidal effect (no growth), whereas plain text valuers indicate bacteriostatic effect (slight growth detected)

The results showed that PoPac had the highest $(p<0.05)$ contents of all phenolic compounds identified followed by PoPm. The major compound found in PoPm and PoPac was PC $(p<0.05)$ while in PoPea it was EA. The results obtained were similar that to those reported by other authors (Sarkhosh et al., 2007; Lu, Ding, and Yuan, 2008; Gullón et al., 2016) who mentioned that the most abundant polyphenolic compounds in pomegranate peel were PC followed by EA.

However, the use of organic solvents in the manufacturing process of food ingredients, in general and in organic food in particular, is regulated and environmental aspects should be taken into account related of the use of them as the solvents used for extraction (Tabaraki, Heidarizadi and Benvidi, 2012), in this case acetone and methanol are both biodegradable.

\section{MIC determination}

The MICs, expressed in $\mathrm{mg} \cdot \mathrm{mL}^{-1}$, of the extracts are presented in Table 2. All extracts showed antimicrobial activity against all bacteria tested except PoPea against $A$. denitrificans. $L$. innocua was inhibited in the presence of $50 \mathrm{mg} \mathrm{mL}^{-1}$ of all PoPx. No statistical differences were found $(p>0.05)$ in MICs values of PoPac and PoPm against $A$. faecalis, whilst MIC of PoPea was $100 \mathrm{mg}^{\mathrm{mL}} \mathrm{L}^{-1}(p<0.05)$. As regards, A. denitrificans, PoPea was not effective. In general, the most active extract was PoPac $(p<0.05)$ followed by PoPm.

Inhibitory activity of PoPx against the microorganisms may due to polyphenolic compounds present in the extracts, mainly punicalagins and ellagic acid or their derivatives. High-molecular weight proteins may react with polyphenolic compounds and constitute complex molecules, which can react with oxyreductase (cellular enzymes) that exists in cell walls of bacteria (Tehranifar et al., 2011), impairing the cell membrane structure, leading to a loss of cell homeostasis (Li et al., 2014). There are several works which inform that these compounds have been recorded as having anti-microbial activity (Reddy et al., 2007; Shan et al., 2007; Abuelsaad et al., 2013; Agourram et al., 2013): EA has been reported to have antibacterial activity against both Gram-positive and Gram-negative pathogens (Miguel, Neves, and Antunes, 2010).

\section{Diffusion method}

The antimicrobial efficacy of the PoPx against bacteria was evaluated using a diffusion method to measure the surrounding inhibition zones. Table 3 shows the antibacterial activity of the PoPx $\left(100 \mu \mathrm{L}\right.$ concentration $\left.100 \mathrm{mg}^{\mathrm{mL}}{ }^{-1}\right)$ as determined by applying the diffusion method. All extracts were effective against $L$. innocua being the maximum value for bacteriostatic effect $2.4 \mathrm{~mm}$ which corresponded to PoPm and really scarce for bactericidal effect. As to the other bacteria, both Gram negative, no inhibitory effect was observed using the studied extractsstudied. Given that the inhibitory effect was only detected against the only Gram positive bacteria tested, it may be possible that the nature of the cell wall would be related to the mechanism of action of the extracts. These results showed as well, that compounds in the extracts have little diffusivity to the surrounding environment and that their mechanisms of inhibitory action require the direct contact with the target bacteria. So they would be effective when included in food formulation as well as in antimicrobial coatings or films.

\section{Conclusions}

From the present study, it could be concluded that organic pomegranate peel has antimicrobial activity due to the content of polyphenolic compounds. The polar solvent acetone : water $(70: 30)$ gets the highest extraction yield as well as antimicrobial activity. Pomegranate peel extracts grown by organic agricultural practices could be considered as a possible functional source of additives exerting antibacterial effect against listeria and other psicrophilic psychrophilic bacteria to elaborate organic foods or to be included in films or coatings. 


\section{Acknowledgement}

Author M.C.L. was funded by a FPU grant (Reference number: FPU15/02158) from the Spanish Ministry of Education.

\section{References}

ABATE, G. - MSHANA, R. N. - MIORNER, H. 1998. Evaluation of a colorimetric assay based on 3-(4.5-dimethylthiazol-2-yl)2.5-diphenyl tetrazolium bromide (MTT) for rapid detection of rifampicin resistance in Mycobacterium tuberculosis. In International Journal of Tuberculosis and Lung Disease, vol. 2, 1998 , pp. 1011-1016.

ABUELSAAD, A. S. A. - MOHAMED, I. - ALLAM, G. - AL-SOLUMANI, A. A. 2013. Antimicrobial and inmunomodulating activities of hesperidin and ellagic acid against Aeromonas hydrophila in a murine model. In Life Sciences, vol. 93, 2013, pp. 714-722.

AGOURRAM, A. - GHIRARDELLO, D. - RANTSIOU, K. - ZEPPA, G. BELVISO, S. - ROMANE, A. - OUFDOU, K. - GIORDANO, M. 2013. Phenolic content, antioxidant potential and antimicrobial activities of fruit and vegetables by-products extracts. In International Journal of Food Properties, vol. 16, 2013, no. 5, pp. 1092-1104.

AKHTARA, S. - ISMAIL, T. - FRATERNALE, D. - SESTILI, P. 2015. Pomegranate peel and peel extracts: Chemistry and food features. In Food Chemistry, vol. 174, 2015, pp. 417-425.

AL-ZOREKY, N.S. 2009. Antimicrobial activity of pomegranate (Punica granatum L.) fruit peels. In International Journal of Food Microbiology, vol. 134, 2009, pp. 244-248.

AYALA-ZAVALA, J. - VEGA-VEGA, V. - ROSAS-DOMÍNGUEZ, C. PALAFOX-CARLOS, H. - VILLA-RODRÍGUEZ, J. - SIDDIQUI, M. W. - DÁVILA-AVILA, J.E. - GONZÁLEZ-AGUILAR, G.A. 2011. Agroindustrial potential of exotic fruit byproducts as a source of food additives. In Food Research International, vol. 44, 2011, no. 7, pp. 1866-1874.

CALÍN-SÁNCHEZ, A. - FIGIEL, A. - HERNÁNDEZ, F. - MELGAREJO, P. - LECH, K. - CARBONELL-BARRACHINA, A. A. 2013. Chemical composition, antioxidant activity and sensory quality of pomegranate (Punica granatum L.) arils and rind as affected by drying method. In Food and Bioprocess Technology, vol. 6, 2013, pp. 1644-1654.

GULLÓN, B. - PINTADO, M. - PEREZ-ALVAREZ, J. A. - VIUDA-MARTOS, M. 2016. Assessment of polyphenolic profile and antibacterial activity of pomegranate peel (Punica granatum) flour obtained from co-product of juice extraction. In Food Control, vol. 59, 2016, pp. 94-98.

HASNAOUI, N. - WATHELET, B. - JIMÉNEZ-ARAUJO, A. 2014. Valorization of pomegranate peel from 12 cultivars: Dietary fiber composition, antioxidant capacity and functional properties. In Food Chemistry, vol. 160, 2014, pp. 196-203.
LI, G. - XU, Y. - WANG, X. - ZHANG, B. - SHI, C. - ZHANG, W. - XIA, $X$. 2014. Tannin-rich fraction from pomegranate rind damages membrane of Listeria monocytogenes. Foodborne. In Pathogens and Disease, vol. 11, 2014, no. 4, pp. 1-7.

LU, J. - DING, K. - YUAN, Q. 2008. Determination of punicalagin isomers in pomegranate husk. In Chromatographia, vol. 68, 2008, pp. 303-306.

MIGUEL, M. - NEVES, M. - ANTUNES, M. 2010. Pomegranate (Punica granatum L.): a medicinal plant with myriad biological propertiesa short review. In Journal of Medicinal Plants Research, vol. 4, 2010, pp. 2836-2847.

NUNCIO-JÁUREGUI, N. - MUNERA-PICAZO, S. - CALÍN-SÁNCHEZ, A. - WOJDYLO, A. - HERNÁNDEZ F. - CARBONELL-BARRACHINA, A. A. 2015. Bioactive compound composition of pomegranate fruits removed during thining. In Journal of Food Composition and Analysis, vol. 37, 2015, pp. 1-19.

REDDY, M.K. - GUPTA, S.K. - JACOB, M.R. - KHAN, S.L. - FERRIRA, D. 2007. Antioxidant, antimalarial ad antimicrobial activities of tanninrich fractions, elagitannins and phenolic acid from Punica granatum L. In Planta Medica, vol. 73, 2007, no. 5, pp. 461-467.

SARKHOSH, A. - AMANI, Z. - FATAHI, R. - GHORBANI, H. - HADIAN, J. 2007. A review on medicinal characteristic of pomegranate (Punica granatum L.). In Journal of Medicinal Plants Research, vol. 6, 2007, no. 22, pp. 13-24.

SHAN, B. - CAI, Yi-Z. - BROOKS, J.D. - CORKE, H. 2007. The in vitro antibacterial activity of dietary spice and medicinal herb extracts. In International Journal of Food Microbiology, vol. 117, 2007, no. 1, pp. 112-119.

SMITH-PALMER, A. - STEWART, J. - FYFE, L. 1998. Antimicrobial properties of plant essential oils and essences against five important food-borne pathogens. In Letters in Food Microbiology, vol. 26, 1998, pp. $118-122$.

TABARAKI, R. - HEIDARIZADI, E. - BENVIDI, A. 2012. Optimization of ultrasonic-assisted extraction of pomegranate (Punica granatum L.) peel antioxidants by response surface methodology. In Separation and Purification Technology, vol. 98, 2012, pp. 16-23.

TAJKARIMI, M. - IBRAHIM, S. - CLIVER, D. 2010. Antimicrobial herb and spice compounds in food. In Food Control, vol. 21, 2010, no. 9 , pp. 1199-1218.

TEHRANIFAR, A. - SELAHVARZI, Y. - JHARRAZI, M. - BAJHSG, V.J. 2011. High potential of agro-industrial by-products of pomegranate (Punica granatum L.) as the powerful antifungal and antioxidant substances. In Industrial Crops and Products, vol. 34, 2011, pp. 1523-1527. 